\title{
Phosphate Sorption in Water by Several Cationic Polymer Flocculants
}

\author{
Timothy S. Goebel ${ }^{1}$, Robert J. Lascano ${ }^{1 *}$, Todd A. Davis ${ }^{2}$ \\ ${ }^{1}$ Cropping Systems Research Laboratory, USDA-ARS, Lubbock, TX, USA \\ ${ }^{2}$ Department of Chemistry, United States Air Force Academy, Colorado Springs, CO, USA \\ Email: *Robert.Lascano@ars.usda.gov
}

Received 24 November 2015; accepted 26 February 2016; published 29 February 2016

Copyright (C) 2016 by authors and Scientific Research Publishing Inc.

This work is licensed under the Creative Commons Attribution International License (CC BY). http://creativecommons.org/licenses/by/4.0/

(c) () Op Den Access

\begin{abstract}
Although inorganic phosphate is an essential plant nutrient, elevated levels in surface waters lead to adverse effects in the environment. These effects are attributed to runoff from rain or irrigation events that may cause the sorbed phosphate to be transported from the application sites and to move into neighboring watersheds. Increased phosphate concentration in watersheds may lead to a variety of environmental problems including increased algal blooms, bacterial contamination, and in some cases eutrophication. To overcome these effects, polymer flocculants have been shown to reduce the phosphate concentration in water by removing suspended solids and thereby removing the phosphate sorbed to the solids. The purpose of this study is to determine the amount, if any, of phosphate removed by several commercial polymers. The polymers chosen include the polyacrylamides Magnifloc 494C, Magnifloc 985N and Poly (diallyldimethyl ammonium chloride) (Poly (DADMAC)). Using these polymers, it is discovered that the positive charge density of the polymers affects the amount of phosphate removed from solution with Poly (DADMAC) (having $100 \%$ positive charge density) removing $40 \%$ of the phosphate from a solution containing 10 ppm phosphate.
\end{abstract}

\section{Keywords}

Polymer Flocculants, Phosphate, Sorption, Polyacrylamides, Poly (DADMAC), Smectite

\section{Introduction}

Phosphorus is an essential plant nutrient that is commonly applied as a fertilizer and is frequently found in surface water. Inorganic phosphate contamination leads to a variety of environmental problems with water re-

\footnotetext{
*Corresponding author.
} 
sources including increased algal blooms, bacterial contaminations, and eutrophication of surface water bodies as well as rivers and streams [1]-[5]. The source of phosphate can come from runoff from agricultural fields, land application of wastewater from concentrated animal feeding operations, and municipal wastewater [2] [4] [5]. To help alleviate these adverse effects of phosphate on the environment, methods for the removal of inorganic phosphate from water are needed.

While the removal of phosphate from water is a topic of recent interest, the sorption of phosphate onto polymer flocculants has not been fully investigated [2] [6]-[11]. Polymer flocculants are routinely used to remove solid material from water [12]. They are added to municipal as well as industrial wastewater to remove suspended solids prior to further treatment to remove dissolved contaminants. These polymer flocculants interact with the surface of suspended solids, organizing the individual particles into larger structures called flocs. The flocs then settle out of solution faster as they have a larger diameter than the individual particles. Polymer flocculants can remove contaminants that are bound or incorporated into the suspended solids through the settling process. Recent work by our team has shown that polymer flocculants can be modified to increase the polymers ability to sequester phosphate from solution [7]. The results from that study show that the polymer flocculants are able to remove phosphate as well, but at a lower level than the modified polymers that are developed for that study. However, the commercially available polymers do show a trend indicating that increasing the positive charge density of the polymer results in increased phosphate removal from solution. It is the effect of positive charge density on the amount of phosphate removed from solution that is the focus of this study.

\section{Materials and Methods}

Surface waters have many components including both dissolved and particulate matter. For this study, smectite was chosen to represent the particulate matter present in surface waters as it is a common mineral that has been shown to have slight $\mathrm{H}_{2} \mathrm{PO}_{4}^{-}$sorption [13]. Deionized water was used to control the amount of phosphate present, and $\mathrm{NaH}_{2} \mathrm{PO}_{4}$ (Sigma-Aldrich S8282-550G) was added to create aqueous solutions with different $\mathrm{H}_{2} \mathrm{PO}_{4}^{-}$concentrations.

Cationic and nonionic polymers were chosen for this study. The cationic polymers evaluated were polydiallyldimethylammonium Chloride (100\% positive charge density), Magnifloc 494C (10\% positive charge density), and A14 (40\% positive charge density). A14 was a polyacrylamide made in-house following the synthesis described in our previous work [7]. Magnifloc $985 \mathrm{~N}$ was used as a control polymer with no positive charge (Figure 1).

Three variables were evaluated in this study. First, the amount of smectite was varied to determine the effect on the sequestration of $\mathrm{H}_{2} \mathrm{PO}_{4}^{-}$by the polymers. Second, the amount of time the mixture was stirred was varied to determine if there was a time dependent $\mathrm{H}_{2} \mathrm{PO}_{4}^{-}$sorption maximum for the polymers. Third and finally, the amount of $\mathrm{H}_{2} \mathrm{PO}_{4}^{-}$in solution was varied to determine the sorption maximum.

\subsection{Effect of Increasing the Amount of Smectite Added}

Smectite was weighed and added to a $25 \mathrm{~mL}$ glass Erlenmeyer flask (Kimble KIMAX Flask with ST16 Glass Stopper, Graduated, 26,600) based on the amounts shown in Table 1. $18.5 \mathrm{~mL}$ of deionized water was then<smiles>CC(C)(C)C(C(N)=O)C(C)(C)C(C(=O)OCC[N+](C)(C)C)C(C)(C)C</smiles>

Cationic Polyacrylamide Magnifloc 494C

(MAGC)

(1)

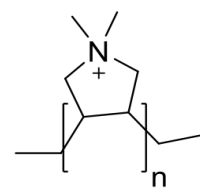

Cationic DADMAC

$(\mathrm{PDM})$

(2)<smiles>CC(C)(C)C(N)=C(C(N)=O)C(C)(C)C</smiles>

Polyacrylamide Magnifloc $985 \mathrm{~N}$

(MAGN)

(3)

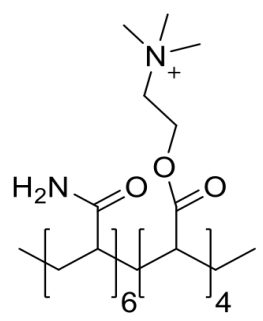

Cationic Polyacrylamide

(A14)

(4)

Figure 1. Chemical structures of polymer flocculants. 
Table 1. Experimental conditions.

\begin{tabular}{cccc}
\hline & Effect of Increasing $\mathrm{H}_{2} \mathrm{PO}_{4}^{-}$ & $\begin{array}{c}\text { Effect of Increasing } \\
\text { Smectite Added }\end{array}$ & Effect of Time \\
\hline $\mathrm{H}_{2} \mathrm{PO}_{4}^{-}$(ppm) & $1,5,10,15,25,30,50,60,75,100$ & 10 & 10 \\
Smectite (mg) & 150 & $25,50,75,100,150,200,250$, \\
& & $300,350,400,500$ & 150 \\
Time (Hour) & 24 & 24 & $0.5,1,2,4,6,8,10,12,14,16$, \\
& & & $18,20,22,24,26,28,30,32$, \\
\end{tabular}

added to the flask, which was sealed using a glass stopper. The mixture was vortexed for $5 \mathrm{~s}$ and the resulting mixture was left for 24 hours to allow the smectite to swell and minimize its phosphate sorption. To this mixture $0.5 \mathrm{~mL}$ of $\mathrm{H}_{2} \mathrm{PO}_{4}^{-}$added a $10 \mathrm{ppm} \mathrm{H}_{2} \mathrm{PO}_{4}^{-}$concentration. The mixture was vortexed for $5 \mathrm{~s}$. To this mixture $1 \mathrm{~mL}$ of the polymer solution was added to make the final polymer concentration of $100 \mathrm{ppm}$ and a final volume $20 \mathrm{~mL}$. The mixture was then vortexed again for $5 \mathrm{~s}$, a stir bar was added to the flask, and sealed with a glass stopper and then placed on a stir plate (JEIO TECH, Multi Channel Stirrer, Model: MS-53M) at 250 RMP for 24 hours. Two control experiments were examined. The first control was to examine the amount of $\mathrm{H}_{2} \mathrm{PO}_{4}^{-}$removed by the smectite. This control was prepared as above but with the addition of $1 \mathrm{~mL}$ of water in place of the polymer. The second control contained only $\mathrm{H}_{2} \mathrm{PO}_{4}^{-}$, no smectite, and $1 \mathrm{~mL}$ of water was added in place of the polymer. After 24 hours, the stir plate was stopped, the stir bars were removed and $8 \mathrm{~mL}$ of solution were placed in a centrifuge tube. The solutions were then centrifuged (Eppendorf Centrifuge 5810) at 3500 RPM for 15 min to remove any solid material that might be present. The supernatant was then filtered through a $0.2 \mu \mathrm{m}$ syringe filter and analyzed for $\mathrm{H}_{2} \mathrm{PO}_{4}^{-}$using a Dionex ICS 2100 ion chromatography system (Suppressor, AERS 5002 $\mathrm{mm}$, Guard and Analytical Column, AG18, AS18) with a $25 \mu \mathrm{m}$ injection loop, running at a flow rate of 0.25 $\mathrm{mL} / \mathrm{min}$ in gradient mode ( $23 \mathrm{mM} \mathrm{KOH}$ for $13 \mathrm{~min}$ then $30 \mathrm{mM} \mathrm{KOH}$ for $12 \mathrm{~min}$ ) resulting in an elution time for phosphate of $23 \mathrm{~min}$.

\subsection{Effect of Increasing $\mathrm{H}_{2} \mathrm{PO}_{4}^{-}$Concentration}

$150 \mathrm{mg}$ of smectite was weighed and added to a $25 \mathrm{~mL}$ glass Erlenmeyer flask (Kimble KIMAX Flask with ST16 GlassStopper, Graduated, 26,600). $18.5 \mathrm{~mL}$ of deionized water was then added to the flask, which was sealed using a glass stopper. The mixture was vortexed for $5 \mathrm{~s}$ and the resulting mixture was left for 24 hours to allow the smectite to swell and minimize its phosphate sorption. To this mixture $0.5 \mathrm{~mL}$ of a $\mathrm{H}_{2} \mathrm{PO}_{4}^{-}$spike added to obtain the various $\mathrm{H}_{2} \mathrm{PO}_{4}^{-}$concentrations listed in Table 1 . The mixture was vortexed for $5 \mathrm{~s}$. To this mixture $1 \mathrm{~mL}$ of the polymer solution was added to make the final polymer concentration of $100 \mathrm{ppm}$ and a final volume $20 \mathrm{~mL}$. The mixture was then vortexed again for $5 \mathrm{~s}$, a stir bar was added to the flask, and sealed with a glass stopper and then placed on a stir plate (JEIO TECH, Multi Channel Stirrer, Model: MS-53M) at 250 RMP for 24 hours. Two control experiments were examined. The first control was to examine the amount of $\mathrm{H}_{2} \mathrm{PO}_{4}{ }^{-}$ removed by the smectite. This control was prepared as above but with the addition of $1 \mathrm{~mL}$ of water in place of the polymer. The second control contained only $\mathrm{H}_{2} \mathrm{PO}_{4}^{-}$, no smectite, and $1 \mathrm{~mL}$ of water was added in place of the polymer. After 24 hours, the stir plate was stopped, the stir bars were removed and $8 \mathrm{~mL}$ of solution were placed in a centrifuge tube. The solutions were then centrifuged (Eppendorf Centrifuge 5810) at 3500 RPM for $15 \mathrm{~min}$ to remove any solid material that might be present. The supernatant was then filtered through a $0.2 \mu \mathrm{m}$ syringe filter and analyzed for $\mathrm{H}_{2} \mathrm{PO}_{4}^{-}$as described above.

\subsection{Effect of Mixing Time of $\mathrm{H}_{2} \mathrm{PO}_{4}^{-}$Sorption}

$150 \mathrm{mg}$ of Smectite was weighed and added to a $25 \mathrm{~mL}$ glass Erlenmeyer flask (Kimble KIMAX Flask with ST16 GlassStopper, Graduated, 26,600). $18.5 \mathrm{~mL}$ of deionized water was then added to the flask, which was sealed using a glass stopper. The mixture was vortexed for $5 \mathrm{~s}$ and the resulting mixture was left for 24 hours to allow the smectite to swell and minimize its phosphate sorption. To this mixture $0.5 \mathrm{~mL}$ of $\mathrm{H}_{2} \mathrm{PO}_{4}^{-}$added to obtain a $10 \mathrm{ppm} \mathrm{H}_{2} \mathrm{PO}_{4}^{-}$concentration. The mixture was vortexed for $5 \mathrm{~s}$. To this mixture $1 \mathrm{~mL}$ of the polymer 
solution was added to make the final polymer concentration of $100 \mathrm{ppm}$ and a final volume $20 \mathrm{~mL}$. The mixture was then vortexed again for $5 \mathrm{~s}$, a stir bar was added to the flask, and sealed with a glass stopper and then placed on a stir plate (JEIO TECH, Multi Channel Stirrer, Model: MS-53M) at 250 RMP for the allotted amount of time described in Table 1. Two control experiments were examined. The first control was to examine the amount of $\mathrm{H}_{2} \mathrm{PO}_{4}^{-}$removed by the smectite. This control was prepared as above but with the addition of $1 \mathrm{~mL}$ of water in place of the polymer. The second control contained only $\mathrm{H}_{2} \mathrm{PO}_{4}^{-}$, no smectite, and $1 \mathrm{~mL}$ of water was added in place of the polymer. After the allotted amount of time, the stir plate was stopped, the stir bars were removed and $8 \mathrm{~mL}$ of solution were placed in a centrifuge tube. The solutions were then centrifuged (Eppendorf Centrifuge 5810) at 3500 RPM for 15 min to remove any solid material that might be present. The supernatant was then filtered through a $0.2 \mu \mathrm{m}$ syringe filter and analyzed for $\mathrm{H}_{2} \mathrm{PO}_{4}^{-}$as described above.

\section{Results and Discussion}

\subsection{Effect of Increasing the Amount of Smectite Added}

The first experiment conducted was to determine the effect of increasing the amount of smectite added to the mixture. It was assumed that as more smectite was added less of the polymer would be available to interact with the $\mathrm{H}_{2} \mathrm{PO}_{4}^{-}$in solution, as it would be adhered to the surface of the smectite particles. The results initially support this assumption as the polyacrylamides generally removed less $\mathrm{H}_{2} \mathrm{PO}_{4}^{-}$with additional smectite added up to $100 \mathrm{mg}$ (Figure 2). The smectite control also showed an increase in $\mathrm{H}_{2} \mathrm{PO}_{4}^{-}$adsorption from $4 \%$ to $10 \%$ at $100 \mathrm{mg}$. The nonionic polyacrylamide MAGN removed an additional 5\% of the $\mathrm{H}_{2} \mathrm{PO}_{4}^{-}$from solution above the amount removed by the smectite alone, up to $100 \mathrm{mg}$ of smectite added. The amount of $\mathrm{H}_{2} \mathrm{PO}_{4}^{-}$removed by MAGC and A14 generally trended downward with the addition of smectite up to $100 \mathrm{mg}$ with A14 removing the most $\mathrm{H}_{2} \mathrm{PO}_{4}^{-}$of all the polyacrylamides at $28 \%$. Generally, the polyacrylamides increased the amount of $\mathrm{H}_{2} \mathrm{PO}_{4}^{-}$removed with increased smectite added, up to $35 \%$ for A14 at $500 \mathrm{mg}$ of smectite added. PDM diverged from these trends by increasing the amount of $\mathrm{H}_{2} \mathrm{PO}_{4}^{-}$removed up to $100 \mathrm{mg}$ of smectite added, followed by a slight decrease in the $\mathrm{H}_{2} \mathrm{PO}_{4}^{-}$removed with increasing smectite added.

The results from the polymers up to the $100 \mathrm{mg}$ smectite addition was likely caused by saturation of the negative charge of the clay by the positive charge of the polymer. When there is a high enough concentration of the cationic polymer flocculant compared to the solid material present the charge of the solid material can become negated, thereby changing net charge of the clay-polymer complex [6] [14] [15]. This has the effect of impairing the polymers ability to form flocs and settle out of solution. The net result of this oversaturation of solid material is dispersion as the now neutral or positively charged smectite-polymer complexes repel each other. Given the smallest amount of smectite added (25 mg to $100 \mathrm{mg}$ ), less of the polymer was available to interact with $\mathrm{H}_{2} \mathrm{PO}_{4}^{-}$in solution so the amount of $\mathrm{H}_{2} \mathrm{PO}_{4}^{-}$removed with increasing smectite weight added was observed. The results from additional amounts of smectite above $100 \mathrm{mg}$ up to $500 \mathrm{mg}$ trended toward more $\mathrm{H}_{2} \mathrm{PO}_{4}^{-}$removed from solution, however, they were also within error of each other. The slight increase in $\mathrm{H}_{2} \mathrm{PO}_{4}^{-}$removed from solution with increasing smectite additions is likely due to sorption of $\mathrm{H}_{2} \mathrm{PO}_{4}^{-}$to the smectite rather than to the polymer. Given these results, $150 \mathrm{mg}$ of smectite was chosen as the amount of smectite that would be added to the following experiments and remain constant as described in Table 1.

\subsection{Effect of Increasing $\mathrm{H}_{2} \mathrm{PO}_{4}$ - Concentration}

As the solution concentration of $\mathrm{H}_{2} \mathrm{PO}_{4}^{-}$increased from $1 \mathrm{ppm}$ to $100 \mathrm{ppm}$ the general trend was an increase in the amount of phosphate removed from solution for all the polymers tested as well as the smectite control (Figure 3). Generally, increasing the amount of one reactant will increase the probability of interaction with the second reactant until the second reactant is completely consumed. In the $\mathrm{H}_{2} \mathrm{PO}_{4}^{-}$concentration range of 1 - 50 ppm, the polymers continued the trend of increasing the amount of $\mathrm{H}_{2} \mathrm{PO}_{4}^{-}$removed from solution with increasing positive charge density of the polymer. For the concentration range of $50-100 \mathrm{ppm}^{\mathrm{H}_{2}} \mathrm{PO}_{4}^{-}$the polyacryla- mides removed the same amount of $\mathrm{H}_{2} \mathrm{PO}_{4}^{-}$as smectite alone and were within error of each other. PDM with $100 \%$ positive charge density consistently removed more $\mathrm{H}_{2} \mathrm{PO}_{4}^{-}$from solution than the other polymers tested. At $100 \mathrm{ppm} \mathrm{H}_{2} \mathrm{PO}_{4}^{-} \mathrm{PDM}$ removed almost $9 \mathrm{ppm}$ of $\mathrm{H}_{2} \mathrm{PO}_{4}^{-}$, however, the error associated with the PDM results began to increase as the concentrations increased above $50 \mathrm{ppm} \mathrm{H}_{2} \mathrm{PO}_{4}^{-}$. From the results

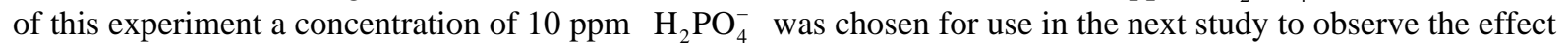


that the amount of time the polymer mixtures were stirred for would have on the amount of $\mathrm{H}_{2} \mathrm{PO}_{4}^{-}$removed from solution.

\subsection{Effect of Mixing Time of $\mathrm{H}_{2} \mathrm{PO}_{4}^{-}$Sorption}

The third and final study examined the effect of mixing time on the amount of $\mathrm{H}_{2} \mathrm{PO}_{4}^{-}$removed from solution. Increasing the amount of time tested the progress of the interaction of $\mathrm{H}_{2} \mathrm{PO}_{4}^{-}$with the polymers. In general, the results again show that an increase in positive charge density of the polymer results in more $\mathrm{H}_{2} \mathrm{PO}_{4}^{-}$removed from solution (Figure 4). The smectite control experiment showed an increase in $\mathrm{H}_{2} \mathrm{PO}_{4}^{-}$sorption from $\sim 2 \%$ to $\sim 7 \% \mathrm{H}_{2} \mathrm{PO}_{4}^{-}$removed in the first two hours. After this the smectite drifted toward more $\mathrm{H}_{2} \mathrm{PO}_{4}^{-}$removed from solution up to $\sim 10 \%$ at 36 hours. The nonionic polyacrylamide MAGN effectively followed the results from smectite alone, removing only what the smectite had sorbed. The MAGC and A14 followed similar trends up to 18 hours with A14 removing more $\mathrm{H}_{2} \mathrm{PO}_{4}^{-}$from solution than MAGC. After 18 hours, A14 and MAGC gen-

Effect of Increasing the Ammount of Smectite

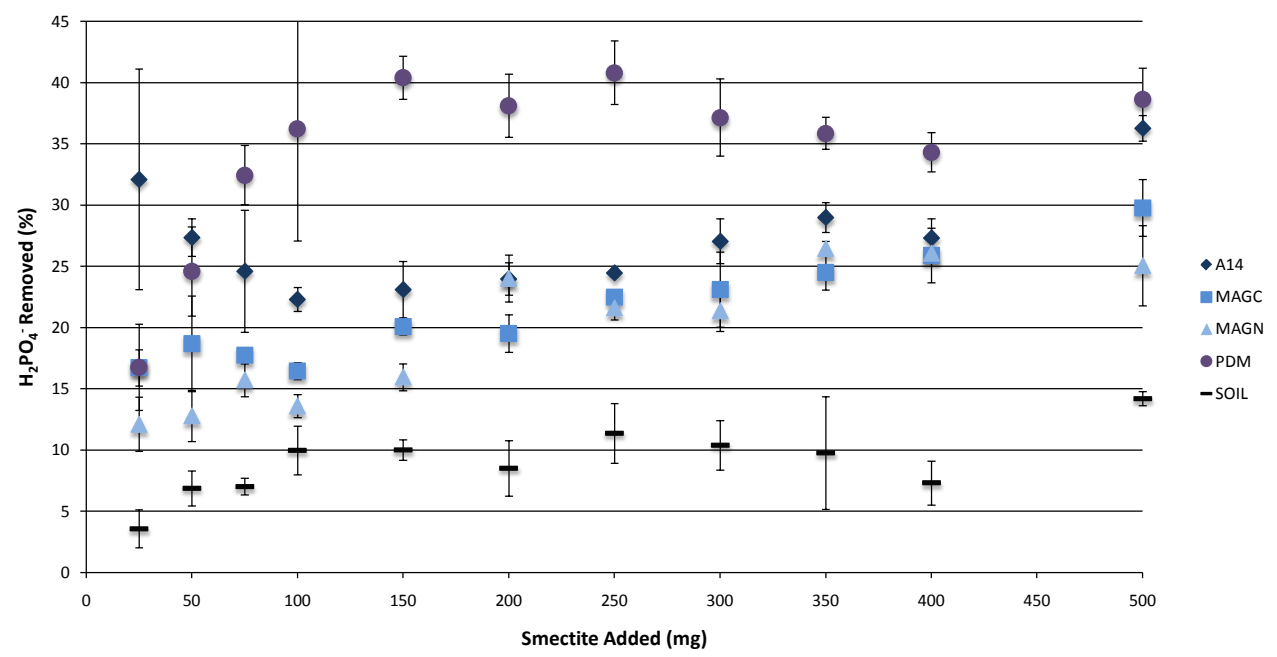

Figure 2. The effect of increasing the amount of smectite added to each flask from $25 \mathrm{mg}$ to 500 mg.

Effect of Increased Phosphate Concentration

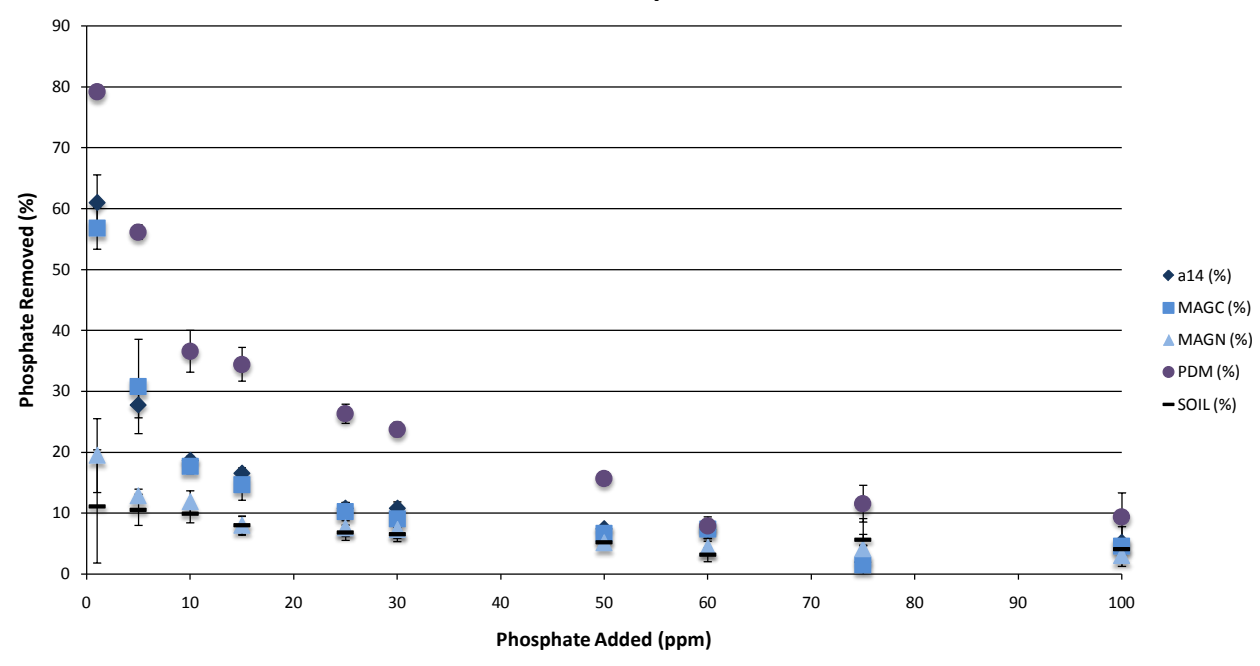

Figure 3. Effect of increasing the solution concentration of $\mathrm{H}_{2} \mathrm{PO}_{4}^{-}$from $1 \mathrm{ppm}$ to $100 \mathrm{ppm}$ on the amount of $\mathrm{H}_{2} \mathrm{PO}_{4}^{-}$removed from solution. 
Effect of Mixing Time on $\mathrm{H}_{2} \mathrm{PO}_{4}^{-}$Removed from Solution

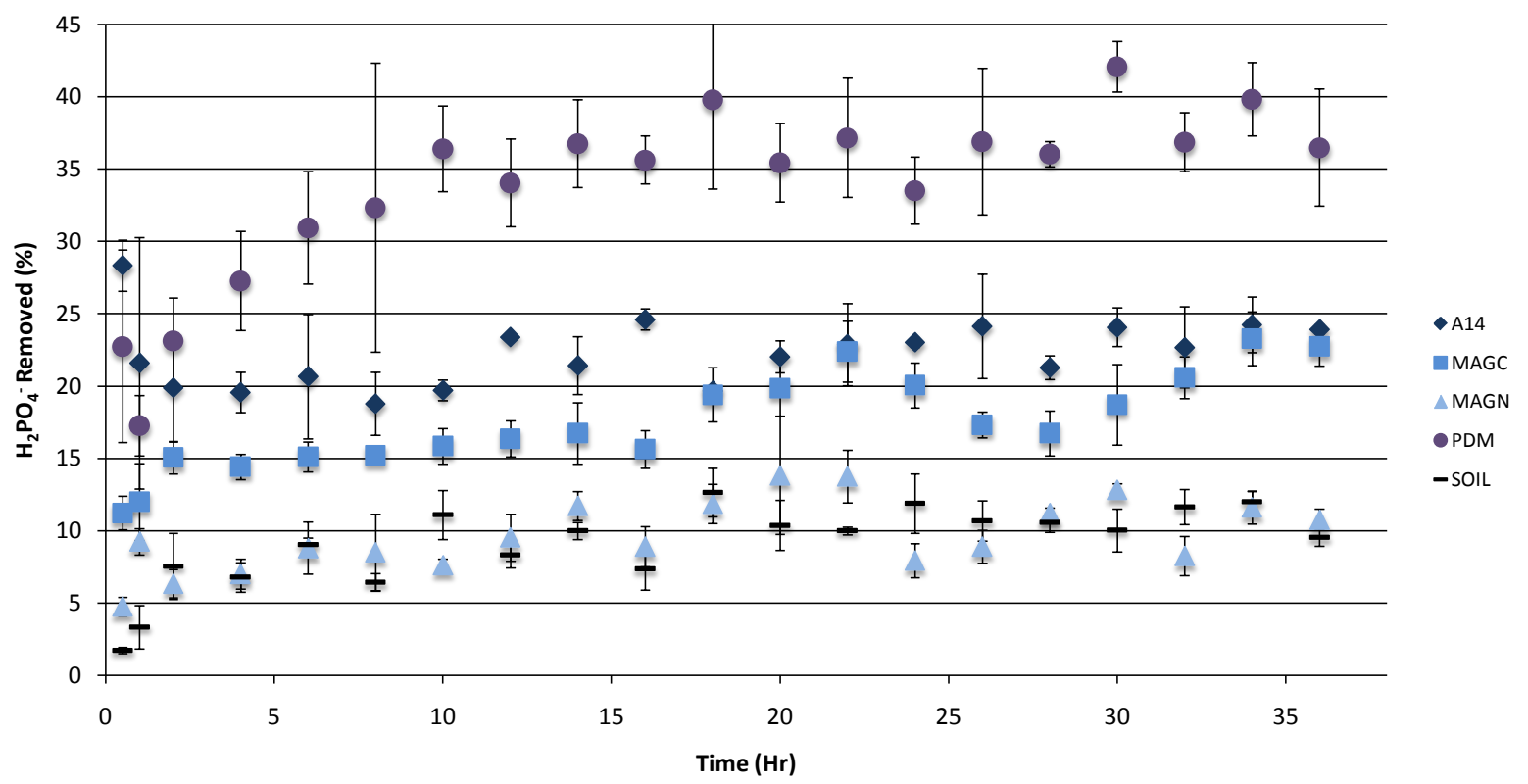

Figure 4. Effect of allowing the mixture to stir for increasing amounts of time on the amount of $\mathrm{H}_{2} \mathrm{PO}_{4}^{-}$removed from solution.

erally removed similar amounts of $\mathrm{H}_{2} \mathrm{PO}_{4}^{-}$. $\mathrm{PDM}$ increased its $\mathrm{H}_{2} \mathrm{PO}_{4}^{-}$sorption up to $~ 35 \%$ at 10 hours and maintained that level of sorption, within error out to 36 hours. In all cases, including the smectite control, the amount of $\mathrm{H}_{2} \mathrm{PO}_{4}^{-}$removed remained constant after the maximum was reached suggesting an irreversible binding.

\section{Conclusions}

The results from these studies show that it is possible to remove $\mathrm{H}_{2} \mathrm{PO}_{4}^{-}$from solution using cationic polymer flocculants. Generally, an increase in positive charge density will increase the amount of $\mathrm{H}_{2} \mathrm{PO}_{4}^{-}$removed from solution, with PDM (100\% positive charge density) consistently removing the most $\mathrm{H}_{2} \mathrm{PO}_{4}^{-}$from solution. The relationship between the charge density and the amount of $\mathrm{H}_{2} \mathrm{PO}_{4}^{-}$removed is not linear, however, with results from A14 with a charge density of $40 \%$ at best doubling the amount of $\mathrm{H}_{2} \mathrm{PO}_{4}^{-}$removed compare to MAGC with a $10 \%$ charge density. The results presented here represent the amount of $\mathrm{H}_{2} \mathrm{PO}_{4}^{-}$removed from solution and it is assumed that the $\mathrm{H}_{2} \mathrm{PO}_{4}^{-}$sorbed to the polymer is the difference between the $\mathrm{H}_{2} \mathrm{PO}_{4}^{-}$ removed by the smectite without the addition of polymer and the amount of $\mathrm{H}_{2} \mathrm{PO}_{4}^{-}$removed when the polymer and smectite are added. The polymers are not extracted and analyzed separately to determine if the $\mathrm{H}_{2} \mathrm{PO}_{4}^{-}$ is bound to the polymer or to the smectite. However, the reproducibility of the effect of positive charge density on the amount of $\mathrm{H}_{2} \mathrm{PO}_{4}^{-}$removed suggests that the $\mathrm{H}_{2} \mathrm{PO}_{4}^{-}$is interacting with the polymers.

The total amount of $\mathrm{H}_{2} \mathrm{PO}_{4}^{-}$removed from solution is small ( $\sim 2$ to $4 \mathrm{ppm}$ ) considering that phosphate concentrations in Concentrated Animal Feeding Operations CAFO wastewater can be greater than 100 ppm [16]. However, the focus of this study is to evaluate the binding of $\mathrm{H}_{2} \mathrm{PO}_{4}^{-}$to the polymers and thus smectite is chosen as it has little $\mathrm{H}_{2} \mathrm{PO}_{4}^{-}$sorption. Smectite does have a high negative charge density, however, that may have resulted in more of the polymer interacting with the surface of the clay particle leaving less of the polymer to interact with the $\mathrm{H}_{2} \mathrm{PO}_{4}^{-}$in solution. Future work will evaluate changing the charge density of the solid material used in the experiments to determine if it has any effect on the amount of $\mathrm{H}_{2} \mathrm{PO}_{4}^{-}$sorbed by the polymers.

\section{Acknowledgements}

This research was supported in part by the Ogallala Aquifer Program, a consortium between USDA-Agricultural 
Research Service, Kansas State University, Texas A\&M AgriLife Research, Texas A\&M AgriLife Extension Service, Texas Tech University, and West Texas A\&M University.

Mention of trade names or commercial products in this publication is solely for the purpose of providing specific information and does not imply recommendation or endorsement by the U.S. Department of Agriculture.

The U.S. Department of Agriculture (USDA) prohibits discrimination in all its programs and activities on the basis of race, color, national origin, age, disability, and where applicable, sex, marital status, familial status, parental status, religion, sexual orientation, genetic information, political beliefs, reprisal, or because all or part of an individual's income is derived from any public assistance program.

\section{References}

[1] Correll, D.L. (1998) The Role of Phosphorus in the Eutrophication of Receiving Waters: A Review. Journal of Environmental Quality, 27, 261-266. http://dx.doi.org/10.2134/jeq1998.00472425002700020004x

[2] Kugimiya, A. and Takei, H. (2008) Selective Recovery of Phosphate from River Water Using Molecularly Imprinted Polymers. Analytical Letters, 41, 302-311. http://dx.doi.org/10.1080/00032710701792919

[3] Livingstone, D.A. and Fleischer, M. (1963) Data of Geochemistry. US Government Printing Office.

[4] Maguire, R.O., Sims, J.T. and Coale, F.J. (2000) Phosphorus Solubility in Biosolids-Amended Farm Soils in the MidAtlantic Region of the USA. Journal of Environmental Quality, 29, 1225-1233. http://dx.doi.org/10.2134/jeq2000.00472425002900040028x

[5] Pote, D.H., Daniel, T.C., Moore, P.A., Nichols, D.J., Sharpley, A.N. and Edwards, D.R. (1996) Relating Extractable Soil Phosphorus to Phosphorus Losses in Runoff. Soil Science Society of America Journal, 60, 855-859. http://dx.doi.org/10.2136/sssaj1996.03615995006000030025x

[6] Bolto, B. and Gregory, J. (2007) Organic Polyelectrolytes in Water Treatment. Water Research, 41, 2301-2324. http://dx.doi.org/10.1016/j.watres.2007.03.012

[7] Goebel, T.S., McInnes, K.J., Senseman, S.A., Lascano, R.J., Marchand, L.S. and Davis, T.A. (2011) Modifying Polymer Flocculants for the Removal of Inorganic Phosphate from Water. Tetrahedron Letters, 52, 5241-5244. http://dx.doi.org/10.1016/j.tetlet.2011.07.130

[8] Kugimiya, A. and Takei, H. (2008) Selectivity and Recovery Performance of Phosphate-Selective Molecularly Imprinted Polymer. Analytica Chimica Acta, 606, 252-256. http://dx.doi.org/10.1016/j.aca.2007.11.025

[9] Muljadi, D., Posner, A.M. and Quirk, J.P. (1966) The Mechanism of Phosphate Adsorption by Kaolinite, Gibbsite, and Pseudoboehmite. Journal of Soil Science, 17, 212-228. http://dx.doi.org/10.1111/j.1365-2389.1966.tb01467.x

[10] Oğuz, E., Gürses, A. and Canpolat, N. (2003) Removal of Phosphate from Wastewaters. Cement and Concrete Research, 33, 1109-1112. http://dx.doi.org/10.1016/S0008-8846(03)00016-4

[11] Patel, J. and Sudhakar, P. (2001) Phosphate Removal from Aqueous Solutions Using Mango Seed Powder. Journal of Industrial Pollution Control, 17, 213-218.

[12] Kawamura, S. (1976) Considerations on Improving Flocculation (PDF). Journal-American Water Works Association, 68, 328-336.

[13] Violante, A. and Pigna, M. (2002) Competitive Sorption of Arsenate and Phosphate on Different Clay Minerals and Soils. Soil Science Society of America Journal, 66, 1788-1796. http://dx.doi.org/10.2136/sssaj2002.1788

[14] Gregory, J. (1973) Rates of Flocculation of Latex Particles by Cationic Polymers. Journal of Colloid and Interface Science, 42, 448-456. http://dx.doi.org/10.1016/0021-9797(73)90311-1

[15] Kasper, D.R. (1971) Theoretical and Experimental Investigations of the Flocculation of Charged Particles in Aqueous Solutions by Polyelectrolytes of Opposite Charge, California Institute of Technology.

[16] Broughton, A., Pratt, S. and Shilton, A. (2008) Enhanced Biological Phosphorus Removal for High-Strength Wastewater With a Low rbCOD:P Ratio. Bioresource Technology, 99, 1236-1241.

http://dx.doi.org/10.1016/j.biortech.2007.02.013 